\title{
INTERNATIONAL LAW APPROACH TO THE MODERN METHODS OF EXECUTING CONDEMNED PRISONERS: ELIXIR TO PAINFUL KILLINGS?
}

\author{
Akingbehin Emmanuel Olugbenga*
}

\begin{abstract}
There is no doubt, that the practice of capital punishment has attracted a barrage of global condemnation. The condemnation is principally because the older methods of execution like shooting, hanging, beheading and crucifixion inflict excruciating pains on the dying offenders, contrary to the prescriptions of the various international instruments. Against the backdrop of the litany of recriminations, some developed retentionist nations invented and adopted the use of some modern methods like electrocution, gas chamber and lethal injection. These modern methods were perceived by the inventing nations to have the advantage of killing swiftly and inflicting minimum pain. This article critically analyses the modern methods of electrocution, gas chamber and lethal injection. The author appraises the history, the practice and the challenges of each of these methods. The article revealed that all the modern methods inflict excruciating pains on the dying offenders, especially as a result of botched executions. The author concludes by making a recommendation for an outright abolition of capital punishment.
\end{abstract}

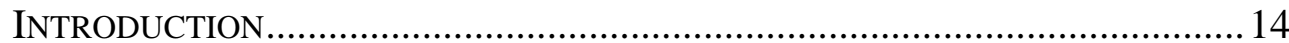

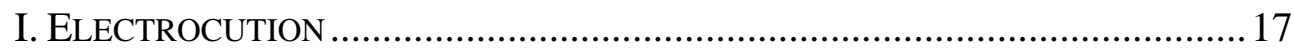

II. GAS CHAMBER ....................................................................... 19

III. LETHAL INJECTION .................................................................. 22

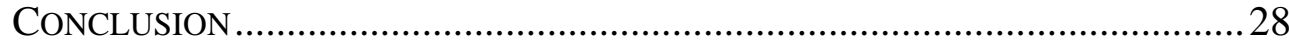

\section{INTRODUCTION}

Condemned prisoners are capital offenders who have been sentenced to death by courts of competent jurisdictions, having been adjudged guilty of capital offences. They are usually placed on the death row while awaiting execution. Generally, in most jurisdictions, the place where condemned prisoners are confined is called "death row". Death row therefore refers to the area in a prison where the inmates awaiting execution are housed, and it is often considered an institutionalised hell. ${ }^{1}$

\footnotetext{
${ }^{*}$ LLB (Ife), BL (NLS), LLM, Ph.D. (Lagos), FCIArb. Senior Lecturer, Department of Public Law, University of Lagos, Akoka, Yaba, Lagos, Nigeria. Research fields: Criminal Law, Criminology and Human Rights.

${ }^{1}$ P. Hudson, Does Death Row Phenomenon Violate a Prisoner's Rights under International Law?, 11 EUROPEAN JOURNAL OF INTERNATIONAL LAW 817 (2000).
} 
Capital punishment therefore, is the premeditated and cold-blooded killing of a human being by the State. It is also the infliction of death by authorized public authority as a punishment. A capital offence can also be defined as an offence, which upon commission and conviction, attracts the penalty of death.

Capital punishment is currently a global issue which has generated much controversy over the years. Different groups and persons have viewed the subjects from different perspectives. Thus, the attitudes of nations vary from one to the other. This variance is confirmed by the fact that the crimes that are capitalized in the retentionist countries differ from jurisdiction to jurisdiction. In some countries, the list is short, while in others, the list is long. Hence, there is no universal yardstick to classify which crime will attract capital punishment. $^{2}$

However, there have been adequate international safeguards for countries that still retain the death penalty to restrict the scope of capitalized offences. It is noteworthy that the U.N. Human Rights Committee, established under the ICCPR has criticized countries with wide scope of capitalized offences in recent years. ${ }^{3}$

Methods of execution of death sentences during the early centuries included boiling, burning at stake, beheading ${ }^{4}$, quartering, hanging,

\footnotetext{
${ }^{2}$ Although, there is an international prescription that the punishment should be imposed by the retentionist countries (if at all) only for most serious crimes. See Article 6(2) of the International Covenant on Civil and Political Rights, adopted December 16, 1966, entry into force March 23 1976, G.A Res 2200 A (xxi): U.N GAOR, 21st Sess. Supp No 16 U N Doc. A/6316 (1966), 999 U.N.T.S 171 (Hereinafter referred to as ICCPR).

${ }^{3}$ M. Sheinin, Capital Punishment and the International Covenant on Civil and Political Rights: Some Issues of Interpretation in the Practice of the Human Rights Committee. Being a paper presented at the EU-China Human Rights Seminar, Beijing, May 10-12, 2001. In Nigeria, for example, the Criminal Code which is applicable only in the Southern parts of the country prescribe capital punishment for the offences of murder, treason, treachery, instigating invasion of Nigeria, and trial by ordeal resulting in murder. See Sections 319, 37, 49A, 38 and 208 respectively of the Criminal Code Act, Cap. C. 38 Laws of Federation of Nigeria 2004. Also, under the Penal Code which is applicable in the Northern states, death sentence is the mandatory punishment for the offences of culpable homicide, abetment of the suicide of a child or insane person, trial by ordeal which results in the death of another, giving or fabricating false evidence which results in the conviction and execution of an innocent person and treason. See Sections 221, 227, 214(b), 159(2) and 411 respectively of the Penal Code (Northern States) Federal Provisions Act, Cap. 345, Laws of Federation of Nigeria 1960. Capital punishment is also prescribed for the offence of armed robbery in the Robbery and Firearms (Special Provisions) Act 1984. Also, with the official adoption of the Sharia Penal Code by some Northern States of Nigeria on October 27th, 1999, Zamfara State with eleven other Northern States have adopted Sharia Penal Code which has widened the scope of capital offences to extend to certain sex-related offences like adultery and sodomy which were formerly punishable with flogging under the Penal and Criminal Procedure Codes. See, for example, Sections 387 and 388 of the Penal Code for the offence and punishment of adultery.

${ }^{4}$ This still happens in Saudi Arabia for drug traffickers, especially.
} 
crucifixion, beating to death, impalement and stoning. However, with the emergence of the abolitionist groups that opposed the execution of condemned prisoners, and public outcry, the issue of the death penalty was revisited and execution methods have been modified in many retentionist countries of the world. Notable amongst the modern execution methods in the world today are electrocution, gas chamber and lethal injection. ${ }^{5}$

In carrying out the execution of the sentence of death, the last wishes of the condemned prisoners are usually fulfilled: That a cleric be allowed to attend to his religious needs, that execution be properly superintended to ensure speedy end and that a medical doctor is available to certify his death. However, no mention is made about the comparative advantages of one mode of execution in minimizing suffering over the other. ${ }^{6}$

It must therefore have been against the backdrop of the above lacuna that the U.N. promulgated some safeguards towards ensuring that a condemned prisoner receives a minimized suffering during execution. Safeguard No. $9^{7}$ declares that where capital punishment occurs, it shall be carried out so as to inflict the minimum possible suffering. In 1996, the Economic and Social Council made it explicit that the safeguard also applied to those under sentence of death awaiting their fates. It urged member states in which the death penalty may still be carried out to effectively apply the Minimum Standard Rules for the Treatment of Prisoners, in order to keep to a minimum, the sufferings of prisoners under the sentence of death, and to avoid any exacerbation of such sufferings.

One may quickly posit at this juncture, that the impression that the death penalty is not a form of torture, inhuman or degrading treatment, may have been informed by the illusion that the modern methods of execution are humane and painless, thereby constituting an elixir to painful killings. This paper therefore seeks to critically evaluate the modern methods of execution against the backdrop of compliance with safeguard No. 9 of the U.N. Economic and Social Council. The paper shall place specific emphasis on electrocution, gas chamber and lethal injection methods.

\footnotetext{
${ }^{5}$ Another method of execution is shooting. The methods that are in use in Nigeria are hanging and shooting. Also the Sharia Penal Code prescribes stoning and crucifixion in certain cases.

${ }^{6}$ R. Hood \& C. Hoyle, The Death Penalty: A Worldwide Perspective 181 (Oxford: Oxford University Press, 2015).

${ }^{7}$ Promulgated by the U.N. Economic and Social Council in 1984 for the Rights of those Facing the Death Penalty in Countries that are Yet to Abolish Capital Punishment. As at date, the total number of retentionist countries in the world are 58, there are 95 abolitionist countries, 35 countries are de facto abolitionists "i.e" countries that retain capital punishment in their statutes but are yet to execute any prisoner for the past 10 years and 9 countries are also abolitionist for ordinary crimes only. http:/www.deathpenaltyinformationcentre.org//execution (last visited January 3, 2016).
} 


\section{ELECTROCUTION}

In 1888, New York became the first state in the United States to adopt electrocution as its method of execution and William Kemmler became the first man to be executed by electrocution in $1890 .^{8}$ Execution by electrocution, sometimes called electric chair, had a bizarre origin, mainly from a New York Dentist, Alfred Southwick. He had the unfortunate opportunity of witnessing the death of an elderly hobo in 1888, when the indigent man accidentally stumbled on an electric generator and died of electrocution. Southwick was then fascinated by the apparent swiftness and perceived painlessness of the man's death. He thereby suggested to a New York state legislator that electricity might alleviate the traumatic results from judicial hangings. ${ }^{9}$

Consequently, the New York Government set up a special commission to investigate how electricity might be used as an alternative to hanging. Thus, after the execution of William Kemmler in 1890, many states quickly adopted electrocution as a primary method of execution. ${ }^{10}$ Electrocution as a method of execution reached a climax stage in 1949 when 26 out of the 48 retentionist states in America had explicit statutes adopting the method.

The electric chair, sometimes referred to as "old sparky" was for a long time in America, regarded as a modern, more efficient and humane alternative to the hangman's rope. ${ }^{11}$ After the adoption of electrocution as execution method by the New York state in 1888, several other states soon followed suit. For example, Ohio in 1896, Massachusetts in 1898, New Jersey and North Carolina in 1907, Virginia in 1908, Kentucky in 1910, while Arkansas, Indiana, Pennsylvania and Nebraska adopted it in 1913. They were apparently motivated by a well grounded belief that electrocution is less painful and more humane than hanging. ${ }^{12}$ The legislation in Texas specifically declared that hanging is antiquated and has been supplanted in many states by the more modern and humane system of electrocution. ${ }^{13}$

However, following the revival of capital punishment in the United

\footnotetext{
${ }^{8}$ See U. Ilo \& O. Ajayi, On the Gallows, Human Rights Law Service 9 (2005).

${ }^{9}$ I. A. Olatunbosun, A Critical Analysis of the Death Penalty in Nigeria. Being a Thesis submitted to the Postgraduate School, Obafemi Awolowo University Ile Ife Nigeria, in partial fulfillment of the award of Ph.D. in Law, at 42 (2004).

${ }^{10}$ The first public execution by electrocution was that of Ruth Syder in New York in 1928, when a journalist apparently stuck a small camera within the death chamber.

${ }^{11}$ A view not shared by the British Royal Commission of 1949-1953. See the United Kingdom Royal Commission on Capital Punishment 1949-1953 Report, at 265, Para. 734 (Cmd 8932, 1953).

${ }^{12}$ Malloy v. South Carolina, 237 US 180, 185, 35 S Cit 507, 59 L. Ed 905 (1915).

${ }^{13}$ Texas, Gen. Laws Ch. 51, SS1, 14. See also W. Schabas, The Death Penalty as Cruel TREATMENT AND ToRTURE 179 (Boston: Northeastern University Press, 1996).
} 
States, after the Supreme Court decision in Gregg v. Georgia ${ }^{14}$ in 1976, the electric chair enjoyed a rather brief vogue as the favoured method of execution. ${ }^{15}$ It was then used in only a few states, notably, Florida, and has been replaced with lethal injection in most jurisdictions. ${ }^{16}$ The United Kingdom Royal Commission also rejected suggestions that electrocution be introduced in that country as a replacement for hanging, though, the commissioners seemed relatively impressed with the electric chair, noting that "unconsciousness is apparently instantaneous", and that "the leg is sometimes burned but the body is not otherwise marked or mutilated." 17 Kirschner also observed that "the brain appears cooked in most cases."

Execution by electricity is normally effected by strapping the condemned person in a wooden chair ${ }^{19}$ and connecting electrodes to his/her body. The head and the right leg will have previously been shaved in order to facilitate attaching the electrodes. The executioner then applies between 2000 and 2,200 volts at the amperage of 7-12 whilst the current is subsequently reduced and re-applied a series of time ${ }^{20}$ until the prisoner is declared dead. ${ }^{21}$

However, in the last three decades of the 20th Century, reports began to circulate about the dramatic instances of botched executions, where the equipment appears to have malfunctioned, to such an extent that flame shots from the prisoner's body with intense muscle spasms generated excruciating pains. $^{22}$ The American Scholar Deborah Denno had summarized the effects of botched execution as follows:

Charring of the skin and severe external burning such as the burning of the ear, exploding of the penis, defecation and micturition, which necessitates the condemned person wearing a diaper, drooling and vomiting, blood flowing from

\footnotetext{
${ }^{14} 428$ US, 135, 176-187 (1976).

${ }^{15}$ Glass v. Louisiana 471, US 1093-1094, S.ct 2159, 2163.

${ }^{16}$ MR Garner, Executions and Indignities: An Eighth Amendment Assessment of Methods of Inflicting Capital Punishment, 39 OHIo STATE L.J. 96-120 (1978).

${ }^{17}$ United Kingdom's Royal Commission Report. Ibid. (n. 11 above), at 251.

${ }^{18}$ Robert Kirschner was the Deputy Chief Medical Examiner of Cook Country.

${ }^{19}$ The chair is constructed of oak and is set on rubber matting and bolted to a concrete floor. The head gear consists of a metal head piece, covered with leather hood which conceals the prisoner's face.

${ }^{20}$ See R. Weisberg, Deregulating Death, SuPREMe COURT REVIEw 305-395 (1983). Electrocution almost never results in instantaneous death, hence, the need for recurrent shocks is common place. See L. J. Hoffman, The Madness of the Method: The Use of Electrocution and Death Penalty, 70 TEX. L. REV. 1039-1041 (1992).

${ }^{21}$ L. E. LAWES, LifE AND DEATH IN SiNG 170 (New York: Double Day, 1928).

${ }^{22}$ Most noticeable were the executions of Jesse Joseph Tafero in 1990, Pedro Medina in 1997 and Allen Lee Davis in 1999. See E. O. Akingbehin, Right to Freedom from Torture, Inhuman or Degrading Treatment in the Context of the Nigerian Criminal Justice System. A Critical Appraisal. Being an unpublished Ph.D. Seminar Paper, delivered to the Department of Public Law, University of Lagos, at 40 (December 2006).
} 
facial orifices, intense muscle spasms and contractions, odour resulting from the burning of the skin and the body and extensive sweating and swelling of skin tissue. $^{23}$

Justice Brennan of the United States Supreme Court also described how an execution in the electric chair can turn out in the following words:

The prisoner's eyes sometimes burst out of his sockets and end up down on his cheeks. He defecates, urinates and vomits blood and saliva. The body turns bright red when the temperature rises, the muscle starts to swell and the skin tightens to the point of bursting. Sometimes, the prisoner catches fire, especially if he's sweating a lot. The witnesses may hear a loud, drawn out sound that is reminiscent of what is heard when you are frying up some bacon and then, a disgusting, cloying smell of burned meat wafts through the chamber. If the voltage is too low, the prisoner is slowly roasted to death. ${ }^{24}$

In the concluding words of Lord Brennam, he stated that even if electrocution does not invariably produce pain and indignities, the apparent century-long pattern of abortive attempts and lingering deaths, suggest that this method of execution carries an unconstitutionally high risk of causing such atrocities. ${ }^{25}$

Sequel to the foregoing, it is suggested that this specie of execution could be construed as a violation of contemporary standards of decency and therefore, a cruel, inhuman and degrading treatment. ${ }^{26}$ It is therefore doubtful, if it satisfies the test of painless killing.

\section{GAS CHAMBER}

Nevada became the first state to introduce asphyxiation by lethal gas as a method of execution in $1924^{27}$ and the first prisoner to be executed with lethal gas was Gee Jon. ${ }^{28}$ The state tried to pump cyanide gas into Jon's cell while he slept but it proved impossible as the gas leaked from the cell,

\footnotetext{
${ }^{23}$ D. W. Denno, Is Electrocution an Unconstitutional Method of Execution? The Engineering of Death over a Century, 35 WILLIAM AND MARY LAW REVIEW 551-692 (1994). The most notable botched executions were witnessed at the executions of Horace Dunkins in Alabama in 1989 and both Derick Lynn Peterson in Virginia, Jesse Joseph Tafero in Florida in 1990.

${ }^{24}$ Glass v. Louisiana. Supra. (n. 15 above) Disssenting.

${ }^{25}$ Ibid. (n. 24 above).

${ }^{26}$ It is on record that the U.S. Supreme Court granted a certiorari order for the first time in 1999 in a case concerning the mode of execution by electrocution in order to consider Florida's use of electric chair. See the case of Bryan v. Moore 528 U.S., 960 (1999). However, in 2000, the court dismissed the case as moot, citing Florida's recent legislation which changed its primary method of execution from electrocution to lethal injection. See also, R. Hood \& C. Hoyle, The Death Penalty: A WORLDWIDE PERSPECTIVE 159 (Oxford: Oxford University Press, 2015).

${ }^{27}$ It was pursuant to the Humane Death Bill of 1921. See W. Schabas, Op. Cit. (n. 13 above), at 189.

${ }^{28}$ U. Ilo \& O. Ajayi, Op. Cit. (n. 8 above), at 10.
} 
which eventually prompted the construction of a gas chamber. ${ }^{29}$

The adoption of the gas chamber to execute death sentence, like the use of electric chair, is essentially restricted to the United States (where both techniques were first developed). Its adoption falls within an unequivocal trend in the United States towards an execution that minimizes pain, suffering and above all, mutilation of the body. ${ }^{30}$

The use of a gas chamber for execution was inspired by the use of poisonous gas in World War I, as well as the popularity of the gas oven as a means of suicide. The execution business is rife with symbolism, and the proponents of the death penalty will point out that similar method is used to put domestic animals "to sleep". The Supreme Court of Nevada, in hearing an early challenge to the gas chamber, also commented on the use of gas by dental surgeons to extract teeth painlessly. ${ }^{31}$

According to the original protocol, the condemned prisoner is to be placed in a special cell for one week, and at an unspecified moment during this period, the valves would be opened while the prisoner is asleep and the prisoner would die without awakening. A challenge to this method was unsuccessful because at that time, the court praised the introduction of the technique as an initiative by the states that "sought to provide a method of inflicting the death penalty in the most humane manner known to modern science." $" 32$

The original protocol was later abandoned in Nevada in favour of a special cell known as the gas chamber and execution was effected rapidly while the prisoner was unconscious. Execution by cyanide gas was subsequently adopted in nine states. ${ }^{33}$

The California gas chamber, which is located at San Quentin state prison, is a modified octagon, approximately seven and a half feet in diameter. There are two chairs and a condemned inmate is trapped in by the legs and arms before execution. A reservoir is located under the chair to hold a mixture of sulphuric acid and distilled water. A cheese cloth bag of sodium cyanide crystals is suspended over the reservoir. There are holes in the seat so that the gas may rise. ${ }^{34}$ Five of the eight sides of the chamber have windows, and chairs are placed outside for witnesses.

Twenty minutes before execution, three pints of U.S.P sulphuric acid

\footnotetext{
${ }^{29}$ Bohm (1999) cited in http://www.deathpenaltyinfo.org (last visited May 11, 2015).

${ }^{30}$ United Kingdom Royal Commission on Capital Punishment. Op. Cit. (n. 11 above), at 255.

${ }^{31}$ State v. Gee Jon. 46 Nev. 418, 211, at 676 (1923).

${ }^{32}$ State v. Gee Jon. Supra (n. 31 above).

${ }^{33}$ These states were Arizona, California, Colorado, Maryland, Mississippi. Missouri, New Mexico,

North Carolina and Wyoming.

${ }^{34}$ See Fierro v. Gomez 865, F. Supp. 1387, 1406 (ND. Cal. 1994).
} 
and six pints of water are carefully mixed in a lead container. The container is covered with a lid of similar material and placed under the chair in a position to receive the pellets when dropped. There are two copper pipes adjacent to the chair, which lead under the floor under the physician's stand. At the end of the pipe, in the chamber, is a rubber hose which is to be connected to the head of a Bowles stethoscope for determining the time of the prisoner's death. ${ }^{35}$

The offender is strapped into a chair in the chamber with all clothes, except shorts removed, in order to eliminate the possibility of pockets of gas remaining in items of clothing. The inmate is restrained at his chest, waist, arms and ankles, and wears a mask during the execution. There are three executioners, and each of them turns one key. When the order is given to commence execution, the three keys are turned and an electric switch causes the bottom of the cyanide container to open, allowing the sodium cyanide crystals to fall into sulphuric acid. This produces hydrocyanic gas, which is inhaled by the prisoner.

Unconsciousness can occur within a few seconds if the prisoner takes a deep breath. However, if he or she holds his or her breath, death can take much longer time and the prisoner usually goes into wild convulsions. A heart monitor attached to the inmate is read in the control room, and after the warden pronounces the inmate dead, ammonia gas is pumped into the execution chamber to neutralize the gas. Thereafter, ammonia gas is removed by a specially constructed exhaust fan. ${ }^{36}$ The neutralizing process takes approximately 30 minutes.

Execution by asphyxiation normally makes use of hydrogen cyanide or hydrocyanic gas. ${ }^{37}$ Expert testimony concerning its effect on humans was considered in 1994 in Fierro v. Gomez ${ }^{38}$ where judge Patel noted that cyanide ingredient, affects many systems within the body. Cyanide that is inhaled, binds to an enzyme system (the cytochrome oxidase system) thereby blocking the transfer of oxygen to cells. ${ }^{39}$ Deprived of oxygen, and thus, unable to produce energy, the cells cease functioning and then die, leading to unconsciousness and eventual death for the person in question. The process is similar to what happens when a person drowns or is strangled. ${ }^{40}$

\footnotetext{
${ }^{35}$ United Kingdom Royal Commission on capital punishment. Op. Cit. (n. 11 above).

${ }^{36}$ W. Schabas, Op. Cit. (n. 13 above), at 190.

${ }^{37}$ Fierro v. Gomez. Supra (n. 32 above).

${ }^{38}$ Supra (n. 33 above).

${ }^{39}$ Gray v. Lucas, 710 F. 2d 1048 (5th Cir. 1983). (Cert. denied) 463, U.S. 1237, 104 S. Ct 211, 77. L. Ed 2d (1983).

${ }^{40}$ W. Schabas, Ibid. (n. 35 above), at 191.
} 
There is no doubt, that cyanide inhalation has a number of other consequences, any of which can be very painful to the prisoner. Deprivation of oxygen leads to generation of lactic acid, which causes acidosis of which the resulting pain is similar to that experienced by a person who is undertaking an intense physical activity or having heart attack. ${ }^{41}$

Considerable controversy and opposition surrounded the use of the gas chamber, which use has always been restricted to the United States. The states that adopted its use have reduced to four and the method is being retained as an alternative to lethal injection. ${ }^{42}$ It is however, unlikely with the barrage of condemnations facing the use of lethal gas, that a prisoner would choose it. ${ }^{43}$ It is however cheering that in the 1994 case of Fierro v. Gomez ${ }^{44}$ a federal judge ruled that California's use of the gas chamber is unconstitutional on the grounds of the time that it took to render the prisoner unconscious. The court held further and acceptably too, that the execution method had no place in a civilized society. What further attestation of cruelty and inhumanity of this method is required? The writer cannot agree more with the learned jurist.

\section{LETHAL INJECTION}

Oklahoma was the first state to introduce lethal injection in the United States in 1977, although it was first carried out in Texas in $1983 .{ }^{45}$ Today, 32 out of the 36 retentionist states in the United States adopted the method as their methods of execution.

Lethal injection, being the latest of the modern methods of execution has very quickly replaced electrocution and lethal gas in most jurisdictions. The condemned prisoner is strapped to a gurney, and a small tube or a cannula is inserted into the vein on one arm at the angle of the elbow. Once

\footnotetext{
${ }^{41}$ H. G. Frank, The Barbaric Punishment: Abolishing the Death Penalty 37-39 (Martinus Nijhoff Publishers, 2003). Dr Richard Traystman of John Hopkins University was reported to have summed up the inhumanity of the gas chamber when he said "we would never even use this method to kill the animals which we use for experiments in our laboratories".

${ }^{42}$ The states are Arizona (if sentenced before November 1992), California, Maryland (if the capital offence occurred before March 1994) and Missouri. Wyoming would only allow it, if lethal injection should prove unconstitutional. See R. Hood \& C. Hoyle, Op.Cit. (n. 6 above), at 184.

${ }^{43}$ In 1992, Robert Alton Harris and others on California's death row brought a class action challenging the constitutionality of the lethal gas method of execution. Though, the Supreme Court rejected the application on the ground that it was belatedly filed, it has generated a lot of furore within the intellectual community. See, S. Reinhardt, The Supreme Court, Death Penalty and the Harris' Case, 102 Yale Law Journal 205-223 (1992); E. Caminker \& E. Chemerinsky, The Lawless Execution of Robert Alton Harris, 102 YALE LAW JOURNAL 225-254 (1992).

${ }^{44}$ Supra. ( n. 33 above). This decision was subsequently upheld by a Federal Court of Appeal.

${ }^{45}$ The first person executed by lethal injection in Texas was Charles Brooks.
} 
the cannula is passed into the vein, a series of substances are injected. ${ }^{46}$

The execution protocol for most jurisdictions authorizes the use of 3drug combination. The first is sodium pentothal (thiopental) which is a rapid acting anaesthetic, a barbiturate, that renders the prisoner unconscious. The second is pancuronium bromide ${ }^{47}$ which is a muscle relaxant that paralyzes the diaphragm, lungs and eventually, respiration. The third is potassium chloride, which stops the heart and causes death.

Prisoners are said to become unconscious within ten to fifteen seconds and death results from anaesthetics overdose and from respiratory and cardiac arrest. ${ }^{48}$ Justice Antonin Scalia of the United States Supreme Court has spoken to the merits of what he calls "a quiet death by lethal injection." ${ }^{49}$ Also, in attesting to the painless effect of lethal injection, a lower court had said that:

...there is a general agreement that lethal injection is at present the most humane type of execution available and is far preferable to the sometimes barbaric means employed in the past. ${ }^{50}$

Another court had also said that there is a national consensus that lethal injection does not violate the American society's evolving standards of decency. ${ }^{51}$

In 2003, a report from the Law Commission of India argued that hanging is a particularly painful method of execution and suggested that lethal injection is "being accepted as the most civilized mode of execution

\footnotetext{
${ }^{46}$ W. Schabas, Op. Cit. (n. 13 above), at 197. On the use of lethal injection, aside from the United States, India, Taiwan, Thailand, Vietnam and Guatemala also make substantial use of the method in executing capital offenders. It was also the method chosen by Phillippines prior to abolition. China also adopted the use of lethal injection where mobile vans equipped for the purpose have been employed to go from area to area. See Use of the Death Penalty in India and New Delhi, South Asia Human Rights Documentation Centre 21-26 (2004), Amnesty International Report 2006, at 281; See also, AgenCe France Presse, 8 (February 10, 2006).

${ }^{47}$ A paralytic agent also called Pavulon. It must be noted that the states of Ohio and Washington have resorted to the use of a single drug protocol in 2009 and 2010 respectively. See State of Ohio v. Riviera (2008), quoted in D. W. Denno, For Execution Methods Challenges, the Road to Abolition is paved with Paradox, In THE RoAD to ABolition 202 (C. J. Ogletree and A. Sarat eds., New York: NYU Press, 2009), where the State Chief Judge held that "a single dose of anaesthetic drug (sodium thiopental) will cause death rapidly and without the possibility of causing panic to the condemned". It is on record that Kenneth Biros became the first person to be put to death by a single dose of Sodium thiopental, when Ohio executed him on 8 December, 2009, an execution that some critics likened to human experimentation; See I. Urbina, New Execution Method is Used in Ohio, THE New YorK TIMES (December 9, 2009). Ohio has thereafter resorted to the use of a single dose of pentobarbital.

${ }^{48}$ H. Hillman, The Possible Pain Experienced during Execution by Different Methods, PERCEPTION 745-747 (1993).

${ }^{49}$ See, Callis v. Collins (Cert. denied) 114, S. Ct 1127, 1128, 1271, Ed. 435 (1994) (Scalia J.).

${ }^{50}$ State v. Deputy. 644 A. 2d. 411 (Del. 1994).

${ }^{51}$ Hill v. Lockbart 791. F. Supp. 1388 (Ed. Ark. 1992).
} 
of the death sentence" and that the pain it induces is only as the result of needle prick ${ }^{52}$.

Also, in China, lethal injection is reported as being more humane than shooting. Hu Yungten, the Director General of Research Bureau of Supreme People's Court told the English Language News Daily in 2009 that lethal injection was considered cleaner, safer and more convenient than shooting at execution grounds. He posited thus: ... it is considered more humane as it reduces criminals' fear and pain compared with gunshot execution. ${ }^{53}$

However, the technique is not without flaws. Different problems do arise in cannulating the vein, because inserting the tube involves a degree of expertise, and the exercise cannot be performed by medical professionals. This is because of ethical considerations and Hippocratic Oaths. ${ }^{54}$ Some prisoners are simply not able to receive the injection while others have scarred arms, resulting from suicide attempts or drug abuse ${ }^{55}$. Veins may also be invisible, covered with layers of fat, or so fat, that a needle which pierces one wall goes through the opposite one as well. ${ }^{56}$

There is, therefore, a further indication that a painful death was not necessarily the result of an occasional mishap due to a failure of the system for administering the drugs or due to some physical peculiarities of the person being executed but a characteristic failure of the drug sequence protocol itself. Leonidas Koniaris et al., in buttressing the above position as it applies to some states in the United States concluded thus:

...[t]oxicology reports from Arizona, Georgia, North Carolina and South Carolina showed that post mortem concentrations of thiopental in the blood were lower than required for surgery in 43 of 49 executed inmates (88\%); 21, (43\%) inmates had concentrations consistent with awareness. ${ }^{57}$

The complication, therefore, is that if the injection goes into the muscle

\footnotetext{
${ }^{52}$ Use of the Death Penalty in India 21-26 (New Delhi: South Asia Human Rights Documentation Centre 2004), citing the Law Commission of India.

${ }^{53}$ X. Chuanjiao, Beijing Ready for Lethal Injection, ChINA DAILY (June 16, 2009).

${ }^{54}$ W. Casscelles \& W. J. Curran, The Ethics of Medical Participation in Capital Punishment by Intravenous Drug Injection, 302 New EnG. J. Med. 226 (1980); T. O. Finks, Lethal Injection: An Uneasy Alliance of Law and Medicine, 4 J. LEGAL MED. 383 (1983); See also, G. R. M. Jones, Judicial Execution and the Prison Doctor, LANCET 713 (1990). It is also important to note the statements by the American Medical Association and the National Association of Emergency Medical Technicians on Physicians' Participation in Lethal Injection, http://www.deathpenaltyinfo.org (last visited November 15, 2015).

${ }^{55}$ When the ex-heroin addict Stephen Morin was going to be executed in Texas, it took 41 minutes for the staff to try out the catheter needle on different parts of his arms, which, in and of itself, is an example of physical and psychological torture. See H. G. Frank, Op. Cit. (n. 40 above), at 38.

${ }^{56}$ United Kingdom Royal Commission on Capital Punishment. Op. Cit. (n. 11 above), at 258.

${ }^{57}$ L. G. Koniaris, T. A. Zimmers, D. A. Lubarsky \& J. P. Sheldon, Inadequate Anaesthesia in Lethal Injection for Execution, 365 (9468) THE LANCET 1412-1414 (2005).
} 
instead of the vein, or if the needle is clogged, it can cause severe pain. Hence, when James Autry was executed in March 1984, it took him at least ten minutes to die and for a large portion of that period, he was conscious, moving about and complaining about pain, probably because the needle was clogged.

Another major challenge of the highly medicalized lethal injection process is the effect of the international rejection of capital punishment on the few retentionist countries like the United States and Vietnam. For example, the policy adopted by the European Union and the government of European Countries to prohibit the export of drugs for use in executions has had a very substantial impact on the use of Lethal Injection in the United States especially. After the importation of such drugs ceased, the United States resorted to the use of locally sourced drugs, in particular Pentobarbital. ${ }^{58}$

However, due to the attacks from various quarters, the last U.S. manufacturer of Sodium thiopental ceased production in 2009 and in July, 2013, the U.S. Court of Appeals for the District of Columbia Circuit ruled that the Food and Drug Administration had failed to fulfill its duties when it allowed sodium thiopental (unapproved) to be imported without inspection. It has therefore become increasingly difficult for the U.S. to obtain any barbiturate. ${ }^{59}$ Of a fact, the future supply of lethal drugs to be used in execution in the U.S.A. is very uncertain, as there is no possibility of administering them without a harmful scandal to the authority of the state concerned and the United States as a whole. ${ }^{60}$

There are other numerous reports of executions in the United States where such problems arose and where there were excruciating delays while prison personnel endeavoured to connect the apparatus. In recent cases, prisoners waited hours while technicians struggled to administer the "medication". ${ }^{61}$ There is also evidence that lethal injection is accompanied with pain and suffering for the prisoner. Justice William J. Brennam of the United States Supreme Court has noted that injection, using barbiturates,

\footnotetext{
${ }^{58}$ For example, the British NGO Reprieve persuaded a Pharmaceutical Company in Arkansas not to continue to provide the State Prison Service with injectable Phenobarbital which the state had decided to use in a new protocol in February, 2013 after the three-drug procedure had been struck down by the Supreme Court in 2012. The prisoners had also challenged the use of the untested combination of drugs through the courts on the grounds that it would produce agonizing and degrading effects. See Reprieve, Briefing: Lethal InJeCtions Drug TRADE (London, Reprieve 2010); See also R. Hood \& C. Hoyle, Op. Cit. (n. 6 above), at 39-40, 191.

${ }^{59}$ At the end of 2013, the supply of Phenobarbital was running out; there was only enough for six executions in Georgia, and Ohio had used its last dose in September, 2013. In fact, identities of suppliers/manufacturers of such drugs are being concealed to save them from attacks and threats. See ASSOCIATED PRESS (December 25, 2013).

${ }^{60}$ See for example, U.N. Human Rights Chief Condemns Oklahoma Execution of Clayton Locket, THE GUARDIAN NEWSPAPER (May 2, 2014).

${ }^{61}$ A. I. Index: AMR 51(16) 92 (January 29, 1992).
} 
has its "own risk of pain, indignity and prolonged suffering." 62 Denno also reported that the British Royal Commission's Report of 1953 had questioned both the humaneness and practicality of lethal injection because of the problems that could result from the peculiar physical attributes of many inmates. For example, abnormal vein or the medical ignorance of the executioner. ${ }^{63}$

A newspaper report of the execution of Raymond Landy in Texas in 1988 revealed the following gory scene; ${ }^{64}$

while Landy was strapped to a gurney, the executioner in Texas repeatedly probed his veins with syringes for forty minutes attempting to inject potassium chloride. Then two minutes after the execution began, the syringe came out of Landy's vein, spewing deadly chemicals towards startled witnesses: what officials termed a 'blow out' resulted in the squirting of lethal injection liquid about two feet across the room. A plastic curtain was pulled so that witnesses could not see the execution team re-insert the catheter into Landy's vein. After 14 minutes and after witnesses heard the sound of doors opening and closing, murmurs, and at least groom, the curtain was opened and Landy appeared motionless and unconscious. Landy was pronounced dead 24 minutes after the drugs were initially injected.

The above scene is not a "one off" event. Incidents of botched executions abound substantially, even with the much vaunted modern methods of execution. This has drawn the discomfiture of the abolitionist groups. The most graphic evidence in recent times, of the problems involved with lethal injection have been revealed in the case of Morales v. Hickman ${ }^{65}$ which was heard in February 2006 in Northern District California Court in United States, before Judge Fogel. The plaintiff sought an injunction to stop his execution so that the court could conduct a full evidentiary hearing on his claim that lethal injection put him at risk of suffering excruciating pain. The Judge however denied the plaintiffs request for a delay in execution but rather ordered the use of sufficient amount of sodium thiopental in order to kill the prisoner. $^{66}$

\footnotetext{
${ }^{62}$ Glass v. Louisiana. Supra. (n. 15 above).

${ }^{63}$ D. Denno, When Legislature Delegates Death: The Troubling Paradox behind States' Use of Electrocution and Lethal Injection and What it Says about Us, 63 OHIO STATE LaW JournaL 65-66 (2002).

${ }^{64}$ D. Denno, Execution and Forgotten Eighth Amendment, in AMERICA's EXPERIMENT WITH CAPITAL Punishment 547-577 (J. R. Acker, R. M. Bohm, C. S. Lanier eds., 1998).

65415 F. supp, 2d 1037 (ND Cal. 2006).

${ }^{66}$ The contention of the plaintiff was that, even though five grams of thiopental sodium would render a person unconscious and cause him to cease breathing within one minute of administration, in actual practice, it had not gotten the intended effect in 6 out of 13 executions carried out between 1999 and 2006.
} 
In a subsequent case, ${ }^{67}$ Judge Fogel, distinguishing between the acceptability of the execution protocols and the morality of capital punishment or constitutionality of lethal injection per se, uncovered the astonishing catalogue of critical deficiencies in the way the executions had been carried out in California. According to Fogel:

.... there was inconsistent and unreliable screening of execution team members, a lack of meaningful training, supervision, and oversight of the execution team who, extra ordinarily, almost, uniformly have no knowledge of the nature or properties of the drugs that are used or the risks or potential problems associated with the procedure. He said further that there was unreliable record keeping, improper mixing, administration and preparation of sodium thiopental by the execution team, who work with inadequate lighting in over crowded conditions and poorly designed facilities.

It is worrisome that Judge Fogel, after having identified further that the pervasive lack of professionalism in the implementation of OP 770 (the drug protocol) at the very least is deeply disturbing, however, went ahead to hold that "though the implementation of lethal injection is broken, it can be fixed". ${ }^{6}$

It is submitted that this decision is highly insensate, unconvincing and callous. Thus, having been able to identify the litany of flaws, the learned judge was supposed to have condemned the method and declared it cruel and inhuman. Little wonder, when he said that the Eighth Amendment does not stipulate an entirely painless procedure but merely prohibits "unnecessary and wanton infliction of pain". 69

\footnotetext{
${ }^{67}$ Morales v. Tilton, case No. C. 06219 JFRS: C06 926 JF. RS. Decided on the December 15, 2006. Also, the execution of Angel Diaz on 13th December 2006 triggered off a lot of clamour for the reform of the techniques for the administration of the lethal injection protocol. Diaz was observed to have remained conscious for a protracted period of time before finally dying. His execution took 34 minutes and required two rounds of the lethal chemicals because the first injection punctured the veins but entered the soft tissue, rather than the veins. Witnesses stated that Diaz appeared to be moving, grimacing and trying to mouth-words after the first injection. See, http://www.deathpenalty.info.org (last visited January 3, 2016).

${ }^{68}$ See E. Kreizberg \& D. Richter, But Can it Be Fixed? A Look at the Constitutional Challenges to Lethal Injection Executions, 47 SANTA Clara Law REview 101-158 (2007); See also, S. Shah, How Lethal Injection Reform Constitutes Impermissible Research on Prisoners, 45(3) AMERICAN CRIMINAL LAW REVIEW 65-96 (2008).

${ }^{69}$ He cited Gregg v. Georgia. Supra (n. 14 above) and Cooper v. Rimmer 379 F. 3d 1029, 1033 (9th circuit 2004); See also, A. Liptak, Court Rules on the Kentucky Executions, New York TiMES (November 23, 2006). It was reported in the cited work that Kentucky Supreme Court in November 2006 ruled that the prohibition in the Eighth Amendment merely prohibits cruel and unusual punishment but does not require a complete absence of pain. See also the subsequent decision of Baze v. Rees 1285. Ct 1520 (2008) where the Supreme Court of the United States upheld the Kentucky Supreme Court's decision that the three-drug protocol and the procedures adopted in Kentucky to ensure that it was properly administered did not create a "substantial risk" of excessive pain and as such not sufficient to make it a violation of the Eighth Amendment's prohibition of cruel and unusual punishment and that the execution process was not deliberately designed to inflict pain.
} 
The decision of the United States Supreme Court in Baze v. Rees ${ }^{70}$ has been echoed in Japan in the case of Sunao Takami in 2011, when the constitutionality of hanging him was challenged on the ground of its cruelty. The Osaka District Court however held that hanging does not violate article 36 of Japan's Constitution which prohibits torture, on the sentiment that some degree of suffering during an execution by hanging is inevitable and "has to be put up with"?

Quite recently, Juan E Mendez, the U.N. Special Repporteur on Torture, who devoted his interim report for 2012 to the issue of whether capital punishment inevitably violates the prohibition against torture and cruel, inhumane, or degrading treatment, corroborated the author's view when he concluded thus:

... there is no categorical evidence that any method of execution in use today complies within [this] prohibition...methods of execution currently used can inflict inordinate pain and suffering. States cannot guarantee that there is a pain-free method of execution. ${ }^{72}$

Also attesting to the futility of the quests for attaining painless executions, Jurgen Martschukat has also posited thus:

...for over two centuries, continuous efforts "to improve" execution methods have never led to a painless and gentle death penalty... "killing with kindness" is an oxymoron. ${ }^{73}$

Flowing from the foregoing, it can be deduced that the grotesque illustrations of the cruelty of inflicting capital punishment by lethal injection can be likened to torture. Inasmuch as one is not oblivious of the clamour for the reform of the procedure for the administration of lethal injection, it is highly doubtful if a flawless and effective system can be devised without the co-operation of the medical profession, in executions that employ a highly "medicalized" process.

\section{CONCLUSION}

There is no doubt that the afore-analyzed modern execution methods

\footnotetext{
${ }^{70}$ Supra (n. 68 above).

${ }^{71}$ The Death Penalty Project, The Death Penalty in Japan: A Report on Japan's Legal Obligation under the International Covenant on Civil and Political Rights and an Assessment of Public Attitudes to Capital Punishment 13 (London, The Death Penalty Project Ltd. 2013).

${ }^{72}$ U.N. Doc. A/67?279, Para. 41 (August 9, 2012).

${ }^{73} \mathrm{~J}$. Martschukat, No Improvement over Electrocution or even Bullet: Lethal Injection and the Meaning of Speed and Reliability in the Modern Execution Process, In THE RoAD TO ABolition? The Future of CAPITAL Punishment in the United States 252-278 (C. G. Ogeltree, Jr \& A. Sarat eds., New York: New York University Press, 2009).
} 
were invented and adopted to replace the older methods which were perceived to be inhumane and painful. This paper has been able to critically discuss each of the modern methods with its attendant flaws. It has also revealed that the incidence of botched executions in the said modern methods resulted in the infliction of excruciating pains on the dying prisoners. Consequently, the modern methods still constitute flagrant violations of Safeguard No. 9 of the United Nations Economic and Social Council, of which the Standard Minimum Rules prescribe that the prisoners under the sentence of death be subjected to minimum suffering and not to be subjected to treatments that will exacerbate such suffering.

Okagbue has fiercely contended that the impression that modern methods of execution are painless is illusory, as she stated that none of the methods of execution guarantees a painless death. ${ }^{74}$

It is submitted that the evolution of another sophisticated method beyond lethal injection is not desirable as it would rather result in a placebo instead of panacea. It is hereby suggested that there should be an outright abolition of the death penalty by the retentionist countries, thereby replacing it with life imprisonment. That, to a great extent, would be the elixir to painful killings by the states.

\footnotetext{
${ }^{74}$ I. Okagbue, The Death Penalty from a Human Rights' Perspective, NigERIAN CURRENT LAW REVIEW (NIALS) 143-160 (1995).
} 